encourage tissue vitality. Dr. Goldstein goes on to say that "there is danger in the free use of the syringe in forcing some of the fluids into contact with the remote and healthy areas of the tympanic cavity and thus carrying fresh infection to another point." Now this danger of infecting healthy areas is an objection to the use of the chisel or the burr, but I do not think it applies to the proper use of the syringe. In long-standing cases-for to such I must be understood to refer-there is no part of the middle ear that can be said to be uninfected and yet open to the gentle force of an irrigating fluid, but there are certainly grave objections to the frequent use of the probe in the early stages of treatment. I have certainly never seen extension of mischief after irrigation, nor have $I$ ever failed to note improvement. I doubt if dry dressing per se will ever give so good a result. And I do not think the mastoid operation has as clean a record. The importance of the subject must be my excuse for this little protest. The multitude of neglected cases of otorrhœa remain a reproach to the profession at the close of the nineteenth century.-I am, Sirs, yours faithfully,

F. FAulder White, F.R.C.S. Eng.,

Jan. 16th, 1899 Honorary surgeon to the Coventry Hospital and to

\section{"THE TOPICAL USE OF QUININE IN LEUCORRHCEA.'}

To the Editors of THE LANOET.

SrRs,-Dr. W. W. Hardwicke has done good service in bringing to notice the value of quinine in leucorrhcea and some uterine affections. ${ }^{1}$ I can confirm his observations very confidently, having employed hydrochloride of quinine in all cases of leucorrhoea, granular erosion of the cervix, and in all forms of vaginitis and septic endometritis for a period of eight or nine years. Its action is admirable, this salt of quinine being powerfully antiseptic (vide Martindale's Extra Pharmacopceia) and mildly stringent. As an intra-uterine douche in septic endometritis it is very prompt in effect and perfectly unirritating. For vaginal use I have employed pessaries of $2 \mathrm{gr}$. or $3 \mathrm{gr}$. of the hydrochloride in glyco-gelatin medium, one-drachm or twodrachm size, the glyco-gelatin being made with hazeline (ext. hamamelidis liq.) instead of water. Such pessaries, especially the larger, reduce uterine congestion and cause a remarkable contraction of a flaccid vagina, so that after a few days of their regular introduction at bedtime it is sometimes necessary to employ a smaller speculum for examination. Hydrochloride of quinine is soluble 1 in 36 of water. For douching a grain to the ounce of warm boric acid solution answers well, as also for washing out the bladder. Four grains to the ounce with a little cocaine in boric solution makes a good urethral injection and may be used at the very earliest stage of gonorrhcea. From two to four grains to the ounce of the same salt in boric solution, with or without cocaine as required, is in my experience by far the best lotion for ophthalmia neonatorum and gonorrhoal ophthalmia and also for ulcers following hypopyon. Quinine is now sufficiently cheap to allow of its liberal adoption as an antiseptic in suitable cases, but steel instruments should not be soaked in it.

I am, Sirs, yours faithfully,

Slough, Jan. 10th, 1899

R. Shalders Miluer, F.R.C.S. Eng., \&c.

\section{THE NEW MIDWIVES BILL. \\ To the Editors of THस LANOET.}

SIRs, - The publication of the text of the Midwives Bill of 1899 in THE LANCET of Jan. 7th affords those interested an opportunity of examining its provisions. Your attitude towards midwife legislation has been consistent throughout and during the heat of the discussion on the Bill of 1898 you did not fall tw denounce certain of its provisions and to admit to your coluu ns the views of both the promoters and the objectors. This being so $I$ ask permission to point out a serious flaw or two in the present Bill which, upon the whole, is a great advance and improvement on its predecessors. In THE LANCET of Nov. 12th, 1898, pp. 1283-84, you say : “No Midwives Bill which we have yet seen contains any provision for ensuring that in every serious case a lying-in-woman, however poor, shall have the benefit of qualified medical attendance, and without such provision no Midwives Bill should pass." To this I replied on p. 1365 of your next issue and I am still of the same opinion. There appears to be a rooted objection among the promoters of midwife legislation to strict personal supervision of the practice of midwives by medical men and in this respect there is no improvement in the Bill of 1899. All that is there laid down (vide Clause 9 et seq.) is a general supervision by the medical officer of health or "other practitioner or practitioners." I do not hesitate to say that such "supervision" would be valueless in practice and as the Bill confers equal powers and privileges on midwives by examination and those in actual practice (who can produce a "character") it is manifest that the great bulk of the Gamp class will take out licences under the Act. In what respect therefore would the "poor" who largely employ these women benefit by the Act? There is only one way out of the difficulty and that is by creating a local supervising authority in each sanitary or Poor-law district composed of lay and medical men and women who would control the practice of both classes of midwives in the lying-in room and who would pay their medical staff for one or two visits to the parturient woman and her infant immediately after confinement. As the Bill is clearly intended to deprive the profession of its midwifery practice in addition to the reasons in its memorandum it is only fair and just to both the practitioners and their former patients to adopt this plan. This was the intention of Clause 3 of my own Bill of last year and it was the crux of the Bill drafted by Sir Blundell Maple, M.P. It would never do to leave in the licensed midwife's hands the choice of a "follower" or "consultant" as this Bill would actually do if the supervision be carried out as proposed. The most stringent set of "rules" drawn up by a central board would be helpless in this respect and the midwife would ultimately "control" her supervisor. All resident medical men who practise midwifery should be on the supervising committee and paid a small fee for their duties, otherwise the Bill, if it become law, will ruin midwifery practice and in no way benefit the " poor." The rich of course can take care of themselves.

Mrs. Garrett Anderson in your contemporary ${ }^{1}$ curiously overlooks all this and bestows almost unqualified praise on the new Bill. Apart from what I have already said it would be intolerable to saddle one or even two or three medical men with no legal training and perhaps prejudiced in the midwives' favour with such duties as the investigation of " charges of malpractice, negligence, and misconduct," as well as powers of "suspension" in cases of infectious disease. The former are police duties and the latter would most likely displace the midwife and leave the case in the hands of the medical officer of health. I have already occupied so much of your valuable space that $I$ will only further point out that the negative prohibition in Clause 3 , Subsection 4, would not hinder the midwife from giving attendance to mother and child during the lying-in period, nor from giving information to the registrar of births and deaths which might be accepted or not by that official. This is all the more important at present as various attempts are being made by unregistered persons to override the Registration Act; and with regard to the former point it has already been claimed as part of the new midwife's duty to attend slight ailments in both mother and child after parturition. ${ }^{2}$ It is necessary to make positive provision against such conduct in the Bill itself. Strict "supervision and control" are the very essence of midwife legislation and in this respect the present Bill is as faulty as its predecessors.

I am, Sirs, your obedient servant,

Fast Sheen, Jan. 8th, 1899. ALEXANDER MCCook WEIR.

\section{"KYNOMANIA."}

To the Editors of THE LANCET.

Sirs, - In the issue of THE LANCET of Jan. 14th, p. 109, I notice under the above heading the following passage: "In our opinion the state of the law as regards dangerous dogs wants altering. We believe that no dog can be considered dangerous and its owner punished should it bite anyone

Brit. Med. Jour., Jan. 7th, 1899

2 Vide Contemporary Review, Marcb, 1898. 